Article

\title{
Contribution of Natural Forest Products to Rural Livelihoods at Mavunde and Sambandou Villages, Vhembe Biosphere Reserve, South Africa
}

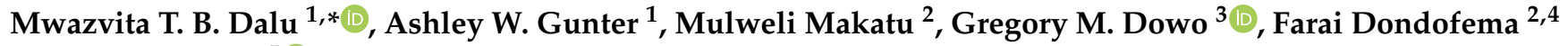 \\ and Tatenda Dalu 5
}

1 Department of Geography, University of South Africa, Pretoria UNISA 0001, South Africa; gunteaw@unisa.ac.za

2 Department of Ecology and Resource Management, University of Venda, Thohoyandou 0950, South Africa; mulwelimakatu33@gmail.com (M.M.); farai.dondofema@univen.ac.za (F.D.)

3 Department of Biological Science and Biotechnology, Midlands State University, Gweru, Zimbabwe; dowog@staff.msu.ac.zw

4 GIS Resource Centre, University of Venda, Thohoyandou 0950, South Africa

5 School of Biology and Environmental Sciences, University of Mpumalanga, Nelspruit 1200, South Africa; dalutatenda@yahoo.co.uk

* Correspondence: smazvita@gmail.com

Citation: Dalu, M.T.B.; Gunter, A.W.; Makatu, M.; Dowo, G.M.; Dondofema, F.; Dalu, T. Contribution of Natural Forest Products to Rural Livelihoods at Mavunde and Sambandou Villages, Vhembe Biosphere Reserve, South Africa. Sustainability 2021, 13, 4252. https:/ / doi.org/10.3390/su13084252

Academic Editors: Grigorios L. Kyriakopoulos and Vítor João Pereira Domingues Martinho

Received: 5 February 2021

Accepted: 1 April 2021

Published: 12 April 2021

Publisher's Note: MDPI stays neutral with regard to jurisdictional claims in published maps and institutional affiliations.

Copyright: (C) 2021 by the authors Licensee MDPI, Basel, Switzerland. This article is an open access article distributed under the terms and conditions of the Creative Commons Attribution (CC BY) license (https:/ / creativecommons.org/licenses/by/ $4.0 /)$.
Abstract: With $\sim 70 \%$ of the sub-Saharan population living in rural areas, more than $90 \%$ of rural African households depend on natural forest products. Although several studies in other parts of South Africa have looked into the use of natural forest products in poverty alleviation, little is known on the roles and relative contribution of natural forest products as daily and safety nets specifically within the Vhembe Biosphere Reserve, South Africa. This study assessed the different roles played by natural forest products in households and the patterns of their relative contribution to households both as sources of income and direct consumption within differing household compositions as well as socio-economic factors. These included employment and income diversification role and the monetised value of natural resources in the rural livelihoods of households in Sambandou and Mavunde, Vhembe Biosphere Reserve, Limpopo Province, South Africa. The study inter alia compared a wide use of natural resources by two villages and determined on which forest products they most relied for their economic welfare. Their relative contributions to livelihoods were assessed by identifying factors that affected their contributions. Findings of the study showed that Sambandou had a high number of people with formal jobs and females, and fewer old-age pensioners. Differences in employment and education between villages were observed. In all villages, the most frequently used or harvested resource was fuelwood, wild edible fruits, herbs, grass/shrub hand sweepers, insects for food, thatch grass/reeds and poles for fencing and housing. Overall, Mavunde village households were found to be more dependent on natural resource harvesting both for income and subsistence substitution. Findings suggest that this may have been a consequence of socio-economic factors such as income and employment, as well as general underdevelopment in the village. This study's findings could contribute to further studies into how these results compare to other parts of the country and region, as well as their respective developmental implications.

Keywords: fuelwood; livelihoods; natural resources; non-timber forest products; Vhembe Biosphere Reserve

\section{Introduction}

Natural resources such as forests, woodlands and coastal mangroves are crucial for the well-being of humanity [1]. Africa is well-endowed with large tropical forests, having the potential to meet the socio-cultural, economic and ecological needs of its population. The continent's 635 million hectares of forests and woodlands account for $21.4 \%$ of its land 
area and about $17 \%$ of global forests [2]. More than 1.6 billion people worldwide depend on forests for natural forest products, and more than $90 \%$ of rural African households depend on natural forest products [3]. Thus, these natural forest products account for approximately $6 \%$ of the gross domestic product of several developing countries and account for an estimated USD 25 billion [3,4]. Forests not only serve as a livelihood source for rural households but also for those in peri-urban and urban settings, providing a wide variety of essential goods and services such as food, medicines, fodder and wood, in addition to spiritual renewal, recreation and safety nets during times of adversity [2,5-8]. Indigenous forest plays a significant role in the lives and economics of rural inhabitants. Population growth and lack of knowledge on sustainable natural resource use amongst the populace have increased the unsustainable exploitation of natural forests for various purposes [9]. This has resulted in acceleration of climate change (ibid.). Thus, it is important to have an understanding of how natural forest products are currently being utilised by households so as to allow for the planning of their future sustainable use.

With $\sim 70 \%$ of the sub-Saharan population living in rural areas, many of them are involved in agriculture. Therefore, harnessing environmental natural resources to satisfy the increasing demands of the world's ever-growing population is compromising the Earth's ecosystems' sustainability, which are important to our survival [10]. This is exacerbated by the role of natural resources in rural livelihoods and poverty alleviation strategies [11-13]. Over and above poverty alleviation, the use of natural forest products in rural livelihoods in sub-Saharan Africa plays a multiplicity of roles, such as supplementing income and providing household nutrition and daily food consumption - that is, as a daily net; and/or acts as a cost-saving mechanism for rural households as a safety net [14-17]. Natural forest product consumption also contributes to better nutrition in many rural households [18].

There are gender disparities in the access to, use and control of resources in many rural communities within sub-Saharan Africa. Eight out of ten people who engage in farming are women, producing $80 \%$ of the food consumed, and doing $90 \%$ of the work to process it [19-21]. According to the IUCN report, women account for $\sim 70 \%$ of the world's poor and account for up to $90 \%$ of forest product harvesting for consumption in forest-dependent communities. Women's livelihoods and social roles within rural areas rely directly on forest resources to meet the health, nutritional and cultural needs of communities and families [1]. In sub-Saharan Africa, resource allocation is mainly a male domain, with women's access to natural resources mostly dependent on kinship and marriage [21-23]. The ownership and utilization of land are governed by patriarchy. Women have use rights but not full access rights to most natural resources within their communities, and this has implications for their livelihoods, since the resources that women access-related to the forest, land and wildlife-have low economic value compared to those enjoyed by men [24,25].

Although several studies in other parts of South Africa [26,27] have looked into the use of natural forest products in poverty alleviation, little is known on the roles and relative contribution of natural forest products specifically within the Vhembe Biosphere Reserve, South Africa. Context specificity is necessary for the development of any responses into poverty alleviation, as there are often different dynamics within specific regions or communities [28]. Thus, taking an in-depth look into context-specific roles played by natural forest products within the Vhembe Biosphere Reserve communities, as well as their relative contributions, can give an indication of the extent to which the natural environment can buffer impoverished communities from absolute poverty. Thus, stakeholders involved in the development of poverty-alleviation strategies (e.g., the local government) can therefore better plan for the sustainable inclusion of the natural environment within these strategies.

The current study therefore aimed to identify roles and contributions played by natural forest products in rural livelihoods within the Vhembe Biosphere Reserve and also to (i) identify the differing roles played by natural forest products in households as either daily, safety and/or emergency nets; (ii) investigate the differentiated relative contributions of natural forest products to households both as sources of income and for household consumption within differing household compositions; and (iii) identify the factors that 
result in higher or lower relative contributions of natural forest products to households as they relate to the availability of and access to the products, as well as socio-economic factors that include employment and income diversification. For the purposes of this research, natural resources refer to all products that are sourced from natural forests, or those that grow or are produced within the natural environment, with little or no human interference. This therefore excludes any arable farming products, as well as any products from domestic animals, such as livestock.

\section{Methods}

\subsection{Study Area}

This study was conducted in Sambandou $\left(22.7383500^{\circ} \mathrm{S}, 30.6530400^{\circ} \mathrm{E}\right)$ and Mavunde $\left(22.7041^{\circ} \mathrm{S}, 30.7752^{\circ} \mathrm{E}\right)$ villages within the Thulamela Municipality, Vhembe Biosphere Reserve, Limpopo Province, South Africa (Figure 1). Sambandou village has a population of 826 inhabitants an area of $2.03 \mathrm{~km}^{2}$, and Mavunde has a population of 2215 inhabitants, with an area of $7.49 \mathrm{~km}^{2}$ [29]. The study area is characterised by dry winters and wet summers, with average annual rainfall of $\sim 608 \mathrm{~mm}$. The study area forms the headwaters of the Ramsar declared wetland (i.e., the Makuleke wetlands found within Kruger National Park). The Sambandou wetlands are located next to the study villages. The hilly landscape is dominated by wetlands and extensive grasslands within the valleys, with interspersed woodland and forest patches. The vegetation is classified as forest, bush and thickets, and forest cover is highest close to the riparian zones of rivers [30]. The dominant and prominent woody species found and utilised within the study area are presented in Table S1.

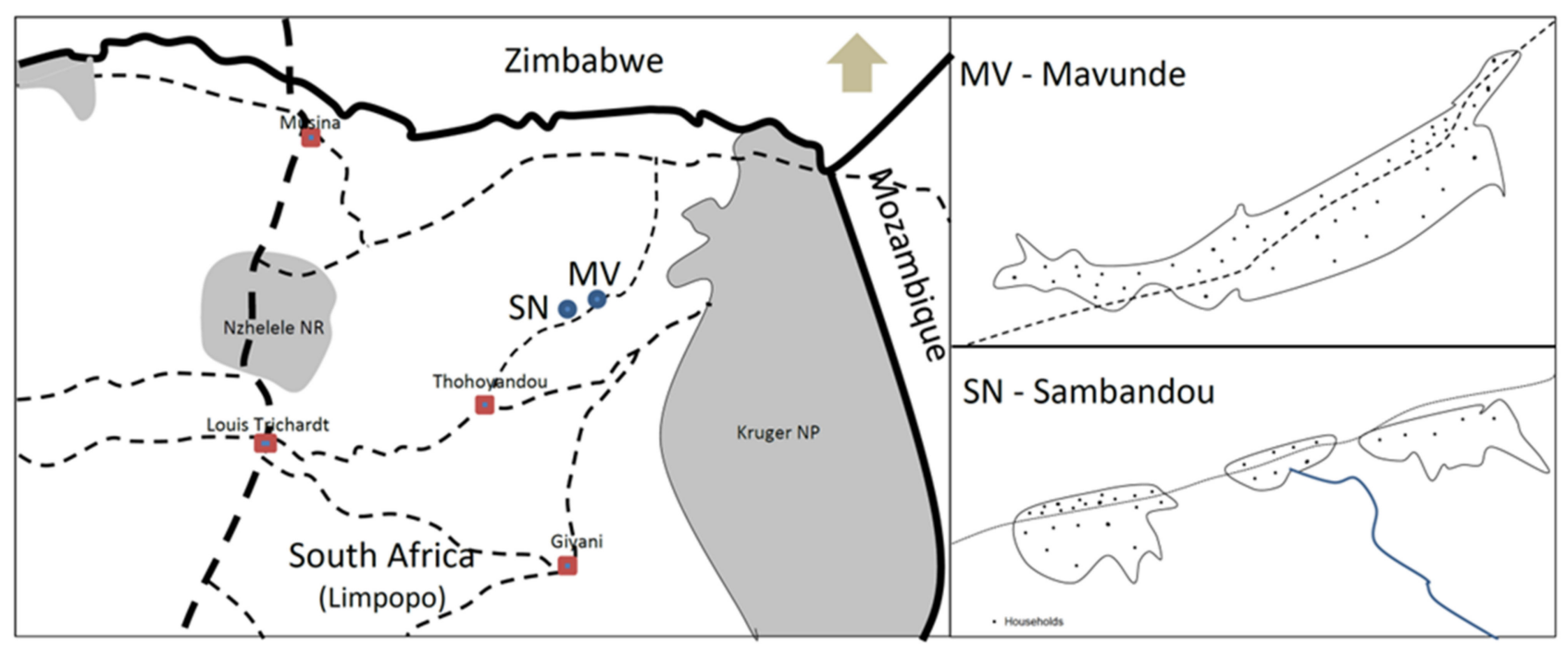

Figure 1. Map showing the study villages and households (dots) sampled within Limpopo province, South Africa.

\subsection{Sampling and Data Collection}

In total, 80 households in two villages (Sambandou-46; Mavunde-34) responded to the questionnaires. Within the Thulamela municipality, there were an estimated total of 130,320 households across 187 main areas, including villages [31,32]. Mavunde had an estimated total of 412 households in 2011, whilst Sambandou had approximately 201 households (adrianfrith.com; accessed on 23 May 2020). The two villages were sampled for convenience, being easily accessible and familiar to the researcher, whilst stratified random sampling was used to select the households across the two villages. Data was collected between the 12 and 13 June 2018. The questionnaire was composed of four sections: (i) the demographic details of the household; (ii) the household economic activities that included employment and income; (iii) how natural forest products were used in the household; and (iv) the types, amount and value of natural products used or bought (see Text S1). Questionnaires were conducted using English and the local language which is TshiVenda 
where necessary to prevent misunderstanding with the respondents, whilst responses were recorded in English. A responsible adult within the household was chosen as a respondent for each sample household.

Verbal informed consent was first given prior to any data that was collected from participants. The researcher took into account all matters of health and safety in conducting this study, applying all standards of confidentiality and anonymity. This research was based on voluntary participation, and no individuals were forced to participate. All questionnaires were administered to the household head or second most senior household member during the day by the researcher. The questionnaire interviews were held at the respective households during the day, lasting approximately $20 \mathrm{~min}$ each.

\subsection{Data Analysis}

Means and bar graphs were calculated and produced respectively for each village to examine differences between them using Microsoft Excel. Data was thematically analysed using open coding according to Sachikonye et al. [33]. Data were statistically treated so as to create simplified themes for analysis of the differences between the two villages in relation to natural resource use. Correlations were used to analyse the relationships of natural resource use to sources of income from employment and livestock presence using $\log (x+1)$-transformed data in SPSS version 16 [34]. The variables used in this analysis were "total number of natural resource types used per household" against "employment status" and "total number of livestock per household".

\section{Results}

\subsection{Population Demographics}

Sambandou had the highest proportion of people with formal jobs (56.5\%) and females $(67.4 \%)$, but fewer old-age pensioners (10.9\%). Mavunde had the higher proportion of males $(55.9 \%)$, unemployment rate $(64.7 \%)$ and proportion of people with matric certificate (35.3\%; Table 1). A matric certificate is the high school qualification in South Africa, obtained after a student successfully sits examinations in year 12 of study. A negative significant relationship ( $r=0.73, p=0.015)$ was observed between employment and natural resource use. Literacy levels were higher in Sambandou compared to Mavunde village, as $56.5 \%$ of the inhabitants had primary education. No national- or regional-level data is provided here for comparison due to the differences in measured parameters and the lack of available data after 2016.

Table 1. Household profiles the two villages sampled (i.e., Mavunde and Sambandou).

\begin{tabular}{ccc}
\hline Characteristics & \multicolumn{2}{c}{ Village } \\
\cline { 2 - 3 } & Sambandou & Mavunde \\
\hline Adult males (\%) & 32.6 & 55.9 \\
Adult females (\%) & 67.4 & 44.1 \\
Children (\%) & 56.5 & 26.4 \\
Employment & 56.5 & 20.5 \\
Full-time formal jobs/household (\%) & 10.9 & 20.5 \\
Old-age pensioner (\%) & 10.9 & 20.5 \\
Household with at least one old-age pensioner (\%) & 67.4 & 35.3 \\
Household working (\%) & 32.6 & 64.7 \\
Household not working (\%) & 4.3 & 8.3 \\
Casual job/household (\%) & 6.5 & 2.9 \\
Part-time job/household (\%) & & \\
Education & 56.5 & 20.6 \\
Household with primary education (\%) & 26.1 & 35.3 \\
Household with matric (\%) & 6.5 & 8.3 \\
Household with college certificate (\%) & 10.9 & 2.9 \\
Household with degree (\%) & &
\end{tabular}




\subsection{Livestock Ownership}

In Mavunde and Sambandou, $26.5 \%$ and $21.7 \%$ of households did not own any livestock, respectively (Table 2). Sambandou had a high proportion of households owning domesticated animals, which were mostly chickens (Table 2). The average number of chickens per household was 13 (Sambandou) and 10 (Mavunde). A negative significant relationship $(r=0.68, p=0.021)$ was observed between owning livestock and natural resource use.

Table 2. Livestock ownership within the study villages. SD: standard deviation.

\begin{tabular}{ccc}
\hline Characteristics & \multicolumn{2}{c}{ Village } \\
\cline { 2 - 3 } & Sambandou & Mavunde \\
\hline Household not owning any livestock (\%) & 21.7 & 26.5 \\
Household owning cows (\%) & 11 & 4 \\
Number of cows (mean \pm SD) & $8 \pm 6$ & $14 \pm 0$ \\
Household owning goats (\%) & 43.5 & 20.6 \\
Number of goats (mean \pm SD) & $8 \pm 4$ & $7 \pm 4$ \\
Household owning chickens (\%) & 56.5 & 52.9 \\
Number of chickens (mean \pm SD) & $13 \pm 9$ & $10 \pm 8$ \\
Household owning pigs (\%) & 26.1 & 44.1 \\
Number of pigs (mean \pm SD) & $5 \pm 3$ & $3 \pm 2$ \\
\hline
\end{tabular}

\subsection{Natural Resource Utilisation}

In all villages, the most frequently used or harvested natural resources were fuelwood, wild edible fruits, herbs, grass/shrub hand sweepers, insects, thatch grass/reeds and poles for fencing and housing (Figure 2, Table 3). Indigenous trees were widely used mostly for fuelwood, fencing and building structures (Figure 2a-c, Table 3). Most households in Mavunde (70\%) utilised cut trees, that is, poles for fencing, housing, and making livestock kraals; this compared to approximately $54 \%$ of households in Sambandou (Figure 2a-c, Table 3). Mavunde had a low proportion of households buying fuelwood from traders, while Sambandou had a high proportion of households buying and cutting trees for domestic use and a high proportion of individuals involved in the selling of fuelwood (Table 3). Few households collected wood for carving and furniture, with the majority of households rather buying from markets and traders (Table 3). Few households in Sambandou (6.5\%) and Mavunde (2.9\%) collected bird eggs. This was mostly done by men, and some villagers used them to decorate their houses.

In Sambandou and Mavunde, $45.7 \%$ and $64.7 \%$ had more than one thatched roofed structure respectively. Most of the households harvested grass or reeds from nearby wetlands and forests, and a few households would purchase from traders at about ZAR 400 to ZAR 500 per load or ZAR 50 per bundle. Mavunde households had a high proportion of people harvesting reeds and/or sedges for weaving mats, with no households harvesting reeds and/or sedges for weaving in Sambandou. However, 37.0\% of households in Sambandou and 29.4\% of households in Mavunde preferred to collect reeds and/or sedges for building/construction from the wetlands than to buy from traders.

The majority of households in both villages bought grass/shrub hand sweepers for domestic daily household chores (45.7\%-Sambandou and 73.5\%-Mavunde). Mavunde had a high proportion of households utilising grass/shrub hand sweepers, with the short hand brush being the most commonly used. They bought sweepers from the traders within the villages and the purchasing price varied between ZAR 20 and ZAR 30 (Table 3). Only $13.0 \%$ of households in Sambandou village collected grass/shrubs to make hand brushes for sweeping the exterior of their compounds, and this figure was $55.9 \%$ of households in Mavunde. The proportion of households that used wild plants for medicinal purposes was $17.4 \%$ (Sambandou) and 26.5\% (Mavunde). In each village, different households utilised different plants for medicinal purposes (e.g., marula bark to predict childbirth, and some 
women use it as a powder to heal menstrual pains). Traditional healers also collected roots for initiating babies after birth.

Few households (26.1\%—Sambandou, 17.6\%-Mavunde) consumed bush meat. Households acquired bush meat from hunting by setting wire traps in the forest and fields, whilst some bought game meat from hunters or traders (Table 3). About $44 \%$ of households within the two villages go to the nearby river to fish, and if they caught more fish, they sold the surplus for about ZAR 25 each depending on size. In the two villages, most households harvested insects as a food source (Table 3).

The majority of households in both villages harvested wild fruits to eat and sell (Table 3). Fruits were harvested in $20 \mathrm{~L}$ buckets, plastic and bags. The village community members harvested wild fruits and sold them along the road at ZAR 10 to ZAR 15 per small packet $(100 \mathrm{~g})$. Some of the wild fruits they collect were from trees such as munombelo (milkplum Bequaertiodendron magalismontanum), thaladzi/mbubulu (red milkwood Mimusops zeyheri), muvhungo (rubber vine/san apricot vine Landolphia kirkii), muvhuyu (cream of tartar tree/baobab Adansonia digitata), muzwilo (velvet wild medlar Vangueria infausta), muthondo (wild mango Irvingia gabonensis), muhuyu (false cluster fig Ficus sycomorus subsp. sycomorus) and mufula (cider tree/marula Sclerocarya birrea subsp. caffra). The proportion of households that used wild fruits for brewing beer was similar between the two villages. The two village communities have developed the expertise and knowledge to utilise a variety of wild fruits to brew their homemade alcohol; for example, they brewed alcohol using mufula and wild mango (muthondo) known as mukumbi in Venda and Shona cultures. About $9 \%$ of households in Mavunde collected roots and tubers, and they used them during fermentation, believing that roots give their traditional alcohol a distinctive flavour.

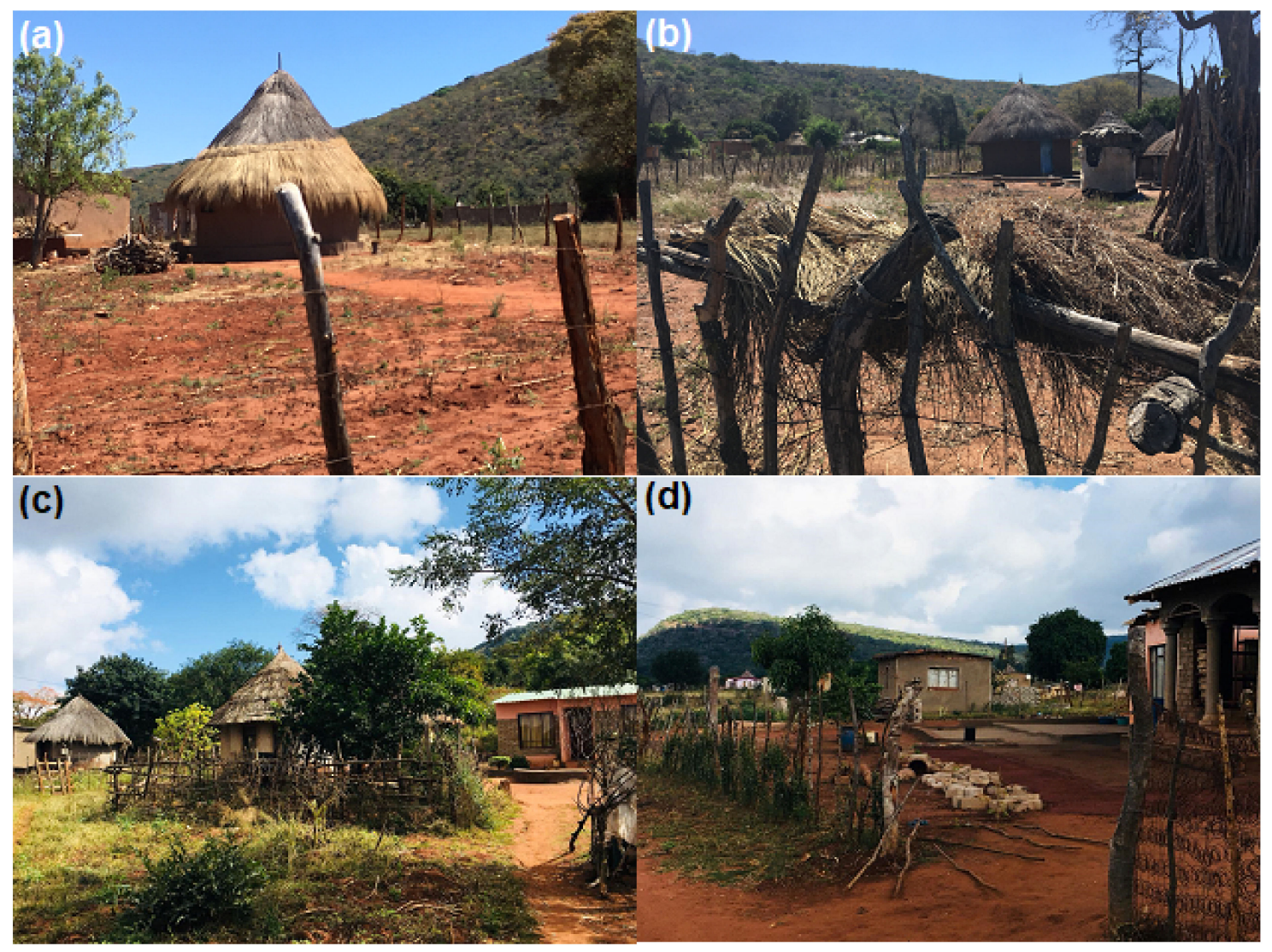

Figure 2. How the Mavunde communities utilise different natural resources: (a) poles for fencing, reeds from wetland being used for thatching and cow dung for plastering; (b) stacked reeds and poles/wood; (c) kraal made from cut tree branches and (d) cow dung being used to making flooring. Photos taken by Tatenda Dalu. 
Table 3. The proportion (\%) of households using specific natural resources at each village. The exchange rate at the time of sampling was USD $1.00=$ ZAR 13.71 .

\begin{tabular}{|c|c|c|c|c|c|}
\hline \multirow{2}{*}{ Natural Resource } & \multicolumn{2}{|c|}{ Sambandou } & \multicolumn{2}{|c|}{ Mavunde } & \multirow{2}{*}{ Unit Price (ZAR) } \\
\hline & Bought & Collected & Bought & Collected & \\
\hline Bird eggs & & 6.5 & & 2.9 & 10 (nest) \\
\hline Fish & & 43.5 & & 44.1 & $30-50(\mathrm{~kg})$ \\
\hline Fuel wood & 28.2 & 71.7 & 17.6 & 61.8 & 400 (load)/40 (bundle) \\
\hline Grass for hand sweepers & 45.7 & & 73.5 & & 25-30 (bundle) \\
\hline Honey beer & & 4.3 & 11.8 & & $30(\mathrm{~kg})$ \\
\hline Insects for food & & 63.0 & & 64.7 & 20 (cup) \\
\hline Medicinal plants & & 17.3 & & 26.5 & 30 (bark) \\
\hline Mushrooms & & 26.1 & & 20.6 & $30(\mathrm{~kg})$ \\
\hline Poles for fencing & & 54.3 & & 70.6 & 40 (bundle) \\
\hline Poles for housing & & 54.3 & & 70.6 & 40 (bundle) \\
\hline Reeds for construction & & 37.0 & & 29.4 & 200 (load)/30 (bundle) \\
\hline Reeds for weaving mats & 10.9 & & & 52.9 & 10 (bundle) \\
\hline Roots or tubers & & & & 8.8 & 10 (bundle) \\
\hline Sand/soil termite mounds & & 15.2 & & 17.6 & $30($ cup) \\
\hline Seeds & 10.9 & & 35.3 & & 10 (packets) \\
\hline Thatch grass & & 45.6 & & 64.7 & 400 (load)/50 (bundle) \\
\hline Traditional beer & & 56.5 & & 52.9 & $10-15$ (cup) \\
\hline Grass/shrubs for sweepers & & 13.0 & & 55.9 & 15 (bundle) \\
\hline Wild animals & & 26.1 & & 17.6 & 700 (full); $40 \mathrm{~kg}$ \\
\hline Wild fruits & & 63.0 & & 70.6 & $10-15$ (packets) \\
\hline Wild herbs & & 32.6 & & 38.2 & 10-15 (packets) \\
\hline Wild honey & & 17.4 & & 11.8 & 40-50 (packets) \\
\hline Wood for carvings to sell & & & & 2.9 & 30 (item) \\
\hline Wood for furniture & & & & 17.6 & 100-300 (furniture) \\
\hline Wood for household items & & 6.5 & & 20.6 & 65 (item) \\
\hline
\end{tabular}

Ten households in the two villages sold natural resources as a source of income, of which four were male- and six were female-headed households. Five female- and three male-headed households sold to the villages, one female-headed household sold to the neighbours and one male-headed household sold resources to friends.

\subsection{Perceptions on the Value of Natural Resource to Community Livelihoods}

In order to validate some of the quantitative data collected on the contribution of natural resources to livelihoods, open-ended questions on the perceptions of interviewees were posed at the end of the questionnaire. Of the two villages interviewed within the Vhembe Biosphere Reserve, 95\% highlighted that natural resources contributed significantly to their daily livelihoods, with $5 \%$ being either negatively affected or neutral about the importance of natural use and contribution to their livelihoods. Of the significant attributes highlighted by most village members were the benefits provided such food, medicine, fuelwood, construction material (poles, grass) and income provision. Culture, recreation (i.e., general beauty and sense of wellbeing) were also identified as other important variables by $\sim 60 \%$ of the community members within both study villages.

\section{Discussion}

This discussion focuses on the results that showed the types of natural resources used in this study. It also discusses their relative contributions to people's livelihoods. This section discusses the various roles that these resources have as coping, daily and safety nets. It also explores the factors that influence those patterns of use of the identified natural resources within the study area. 


\subsection{Livelihood Contribution and Roles of Natural Resources to Households}

The contribution of natural forest products to rural livelihoods for the two study villages (i.e., Sambandou and Mavunde) as a source of food, energy and income provision/generation was noted in this study. The sale of forest products can occur on a regular basis, seasonally as a gap filler or in times of emergency as a safety net $[35,36]$. The sale of non-timber forest products (NTFPs) is particularly important for most vulnerable and marginalised segments of society, and in South Africa has been used especially by rural households to cope with setbacks, with females being the most involved in the trade [15]. Natural resources therefore become a coping strategy, playing a "safety net" role in times of misfortune [5]. Natural forest products were also found to be used as medicine in rural households. The dependency on traditional medicine collected from natural environment is perpetuated by the fact that Western medicine is limited and expensive in rural areas [37]. Forests, grasslands and wetlands were also utilised in the study area as grazing grounds for cattle and goats. Both study villages highlighted a wide use of natural resources; however, the pattern of resource utilisation differed between villages. For example, households in Sambandou and Mavunde utilised 23 and 26 different resource types, respectively (Table 3). This represented the daily net function of natural resources, as energy for cooking or poles and fencing would otherwise had been purchased using money that is potentially being saved by the households. The daily net function of natural resources represents a cost saving to households, and indeed even to the state. The daily net function allows for the accumulation of savings, as it substitutes the use of income. Shackleton and Shackleton [5] found that rural households in South Africa harvested an approximate annual average of 5.3 tonnes of fuelwood, $58 \mathrm{~kg}$ of wild spinaches, $104 \mathrm{~kg}$ of edible fruits and 185 large poles for fencing, kraals and houses. The mean gross, direct-use value across the 14 South African studies was ZAR $3854 \pm 786$ per household per year (equivalent to ZAR 7000 p.a. in 2013) [5]. As cumulative values for income substitution, this can be a significant contribution to income.

Approximately $47 \%$ of community members in the two study villages were unemployed and depended on indigenous forest products for food and income generation. The extent of dependency was associated with lack of employment opportunities and/or poverty. Mavunde had a high rate of unemployment (65\%; Table 1). Sambandou households had more households with full-time employment, fewer pensioners and more livestock owners than Mavunde. Thus, the lack of education and unemployment were the main drivers for Mavunde and Sambandou residents to collect indigenous forest products for sale so as to meet their needs, and to also provide money to pay school fees for their children.

\subsection{Linking Narratives of Development and Sustainability to Use of Natural Resources}

Of the two villages, Sambandou seemed to be more developed in terms of infrastructure and general services such as water and electricity, and this may have contributed to their lower dependence on natural resources compared to Mavunde. Mavunde showed more apparent characteristics of South African rural underdevelopment. The South African context of rural underdevelopment can mostly be attributed to the apartheid mode that aimed to build a first-class capitalist economy for a few, excluding the black majority and creating a legacy of underdevelopment and poverty in the rural areas [38]. Rural underdevelopment is characterised by a lack of or prevalence of poor infrastructure, inadequate access to markets, poor communication links (including the digital divide), geographical barriers as well as education and social services inadequacies (ibid.). However, irrespective of the general underdevelopment, the economic conditions, cultural and recreational services provided by natural resources were reported as important by the majority of people in the study area. Lower formal cash stream and livestock in Mavunde may therefore have resulted in households depending highly on indigenous forest resources. In both villages, $\sim 29 \%$ of households sold natural resources to gain income by selling to friends, family and strangers. The study results suggest that most people that sold natural resources were 
from female-headed households, and were not employed. Thus, selling natural resources was a means of gaining income and sustaining their daily livelihoods. Local trade was highly variable and low, as fewer households were fully involved in the trade/selling of different natural resources (e.g., bush meat, wild fruits, fuelwood). For the majority of natural resources, trade was relatively undeveloped, with just a few households selling particular natural resources on a daily basis. Cash income from trade was high for those that pursued trade as a primary livelihood and poverty alleviation strategy. For those natural resources with significant trade, some households only sold surplus of their collected or gathered natural resources, making any income realised from these sales highly variable. This was dependent upon the availability of the resource, which would limit how much each household was able to consume and have surplus to sell. Availability could also be subject to issues of access.

Challenges to the sustainability of these livelihoods can be summarised as being greatly variable due to fluctuations of the market sizes and prices, seasonal fluctuations in the availability of natural resources, issues of access, limited ability and knowhow of natural resource trade $[5,15]$. Shackleton et al. [15] suggested that the socio-economic context and specifically the nature of property rights as well as the degree of underdevelopment and access to markets influence the use of natural resources as a source of income and subsistence.

The use of natural forest products for the construction of houses, fencing and animal kraals is a common practice in most rural communities of sub-Saharan Africa [7,39-41]. Thus, forest wood and poles were preferred for the construction of traditional structures as these are considered to be highly durable, lasting for 10 to 15 years [9]. Poles from the forests are mostly harvested by men of all ages for sale and household use. The fuelwood trade was traditionally the job of rural women, however, due to the increasing demand for fuelwood (especially by residents from less-developed villages), coupled with the income opportunity from selling fuelwood, men are also engaging in the sale of fuelwood [9]. Studies by Makhado et al. [37] highlighted that those who cannot afford to go to the forests for fuelwood, grass and poles harvesting, especially the elderly, having challenges of access, purchase poles and grass for thatching roofs and for fencing their yards from other residents, similar to our study findings.

More than $60 \%$ of rural people in the Sambandou and Mavunde villages used fuelwood for cooking and heating. This was slightly higher than that observed within the Vhembe Biosphere Reserve region (about 50\%) [37,39,41,42]. Fuelwood collected from nearby forests was preferred for cooking as it was readily available [41,43]. According to Makhado [9], rural inhabitants also perceive cooking with fuelwood to be cheaper than using electricity. Venda and Tsonga elders within the study area preferred porridge cooked using fuelwood as they believed that the porridge tastes better than that cooked using electricity [37]. Thus, this is further sustaining the demand for fuelwood use as a first-choice energy source for cooking and heating within the study area and other rural areas in the region, as electricity and rural poverty are high.

\section{Conclusions}

Sambandou and Mavunde residents extracted multiple natural resources from the surrounding forests, grasslands and wetlands, and the use of these natural resources was largely for home consumption, although there was some small local-level trade. Main factors that influenced households to gather from the indigenous forests were poverty and lack of employment to sustain their livelihood activities. People harvested natural forests for their sustenance and commercial purposes to gain income and for subsistence substitution. The informal occupations and income streams that poor people are involved in can rarely be said to provide a sustainable livelihood or a way out of poverty, except for the minority. There is indeed mixed evidence on the effectiveness of informal safety nets. Shackleton et al. [15] points to a key debate in the narrative of natural products-whether or not their trade can effectively assist in improving livelihoods and income, or whether or 
not it offers very limited options and merely serves as a last resort and possibly contributing to the persistence of poverty. Challenges to the sustainability of these livelihoods can be summarised as being greatly variable due to fluctuations of the market sizes and prices, seasonal fluctuations in the availability of natural resources, issues of access, and limited ability and knowhow of natural resource trade $[5,15]$. As the natural resources meet the daily household needs, this allows the households to use their limited cash resources to secure other household needs and endeavour to accumulate the much-needed asset base for a more secure livelihood, such as educating children or accumulating agricultural capital. It also cannot be ignored that this cost-saving benefit on a household level also spills over onto a national level by the provision of food, shelter, energy and medicine, in the absence of which the state would ultimately have to provide [5]. It is for this very reason that the role that natural resources play in easing poverty and providing additional options for income generation cannot be ignored or trivialised.

Supplementary Materials: The following are available online at https:/ / www.mdpi.com/article/10 $.3390 /$ su13084252/s1, Table S1. Dominant and prominent woody species found and utilised within the study area; Text S1. Questionnaire used during the study.

Author Contributions: M.T.B.D. and T.D.: Conceptualization, investigation, data curation, formal analysis, writing-original draft, supervision. A.W.G., M.M., F.D. and G.M.D.: Writing-review and editing, investigation, data curation, formal analysis. All authors have read and agreed to the published version of the manuscript.

Funding: This research was funded by University of Venda Niche Grant, grant number SES/18/ERM/ 10 and the APC was funded by University of Venda.

Data Availability Statement: All data is readily available from authors on request.

Acknowledgments: M.M. greatly acknowledges the financial support of the NRF BSc Hons Scholarship. Thanks go to Rivoningo Chauke, Salphina Sathekge and Bernad Malesa for assisting with fieldwork. The University of Venda granted Ethical approval to carry out the study within its facilities (Ethical Application Ref: SES/18/ERM/20/0312).

Conflicts of Interest: The authors declare no conflict of interest.

\section{References}

1. Ayodeji, O.J.; Ayodele, A.I.; Reuben, M. Assessment of stakeholders engagement in natural resource management using typologies of participation in Kainji lake national park. Sky J. Soil Sci. Environ. Manag. 2016, 5, 18-25.

2. Food and Agricultural Organisation (FAO). Global Forest Resources Assessment 2005; Forestry Paper 147; FAO: Rome, Italy, 2006.

3. Chirwa, P.W.; Syampungani, S.; Geldenhuys, C.J. The ecology and management of the Miombo woodlands for sustainable livelihoods in southern Africa: The case for non-timber forest products. South. For. A J. For. Sci. 2008, 70, 237-245. [CrossRef]

4. Agrawal, A.; Cashore, B.; Hardin, R.; Shepherd, G.; Benson, C.; Miller, D. Economic contributions of forests. Backgr. Pap. 2013, 1, 1-127.

5. Shackleton, C.M.; Shackleton, S.E. The importance of non-timber forest products in rural livelihood security and as safety nets: A review of evidence from South Africa. S. Afr. J. Sci. 2004, 100, 658-664.

6. Paumgarten, F.; Shackleton, C.M. Wealth differentiation in household use and trade in non-timber forest products in South Africa. Ecol. Econ. 2009, 68, 2950-2959. [CrossRef]

7. Dalu, M.T.; Shackleton, C.M. The potential use of natural resources in urban informal settlements as substitutes for financial capital during flooding emergencies. Phys. Chem. Earth Parts A/B/C 2018, 104, 18-27. [CrossRef]

8. Dalu, M.T.; Shackleton, C.M.; Dalu, T. Influence of land cover, proximity to streams and household topographical location on flooding impact in informal settlements in the Eastern Cape, South Africa. Int. J. Disaster Risk Reduct. 2018, 28, 481-490. [CrossRef]

9. Makhado, R.A. Mopane Wood Utilisation and Management Perceptions of Rural Inhabitants in the Greater Giyani Municipality. Master's Thesis, University of Limpopo, Polokwane, Limpopo Province, South Africa, 2008.

10. Kremen, C. Managing ecosystem services: What do we need to know about their ecology? Ecol. Lett. 2007, 8, 468-479. [CrossRef]

11. Arnold, J.M.; Pérez, M.R. Can non-timber forest products match tropical forest conservation and development objectives? Ecol. Econ. 2001, 39, 437-447. [CrossRef]

12. Wunde, S. Poverty alleviation and tropical forests: What scope for synergies? World Dev. 2001, 29, 1817-1833. [CrossRef]

13. Sunderlin, W.D.; Angelsen, A.; Belcher, B.; Burgers, P.; Nasi, R.; Santoso, L.; Wunder, S. Livelihoods, forests, and conservation in developing countries: An overview. World Dev. 2005, 33, 1383-1402. [CrossRef] 
14. Qureshi, M.H.; Kumar, S. Contributions of common lands to household economies in Haryana, India. Environ. Conserv. 1998, 25, 342-353. [CrossRef]

15. Shackleton, S.; Campbell, B.; Lotz-Sisitka, H.; Shackleton, C. Links between the local trade in natural products, livelihoods and poverty alleviation in a semi-arid region of South Africa. World Dev. 2008, 36, 505-526. [CrossRef]

16. Babulo, B.; Muys, B.; Nega, F.; Tollens, E.; Nyssen, J.; Deckers, J.; Mathijs, E. The economic contribution of forest resource use to rural livelihoods in Tigray, Northern Ethiopia. For. Policy Econ. 2009, 11, 109-117. [CrossRef]

17. Areki, F.; Cunningham, A.B. Fiji: Commerce, carving and customary tenure. In Wild Governance-Finding Policies that Work for Non-Timber Forest Products; Laird, S.L., McLain, R.J., Wynberg, P.L., Eds.; EarthScan: London, UK, 2010 ; pp. $229-242$.

18. Chakona, G.; Shackleton, C.M. Local setting influences the quantity of household food waste in mid-sized South African towns. PLoS ONE 2017, 12. [CrossRef]

19. Murray, C. Livelihoods research: Transcending boundaries of time and space. J. South. Afr. Stud. 2002, 28, 489-509. [CrossRef]

20. Mukadasi, B.; Nabalegwa, M. Gender mainstreaming and community participation in plant resource conservation in Buzaya county, Kamuli district, Uganda. Afr. J. Ecol. 2007, 45, 7-12. [CrossRef]

21. Mukoni, M. Ecological sustainability: Reinvigorate and emulate African principles of life or cease to exist? Int. J. Asian Soc. Sci. 2015, 5, 514-521. [CrossRef]

22. Osemeobo, G.J. Living on the forests: Women and household security in Nigeria. Small-Scale For. Econ. Manag. Policy. 2005, 4, 343-357. [CrossRef]

23. Mwangi, E.; Meinzen-Dick, R.; Sun, Y. Gender and sustainable forest management in East Africa and Latin America. Ecol. Soc. 2011, 16, 12-19. [CrossRef]

24. Bashaw, Z. Trajectories of Women, Environmental Degradation and Scarcity: Examining Access to and Control Over Resources in Ethiopia. Gender, Economies and Entitlements in Africa. Codesria.org. 2004, 1-13. Available online: https://codesria.org/IMG/ pdf/ZENEBE.pdf (accessed on 15 May 2020).

25. Shackleton, C.M.; Shackleton, S.E.; Cousins, B. The role of land-based strategies in rural livelihoods: The contribution of arable production, animal husbandry and natural resource harvesting in communal areas in South Africa. Dev. South. Afr. 2001, 18, 581-603. [CrossRef]

26. Wollenberg, E.; Ingles, A. Incomes from the Forest: Methods for the Development and Conservation of Forest Products for Local Communities; CIFOR: Jakarta, Indonesia, 1998.

27. Cocks, M.L.; Wiersum, K.F. The significance of plant diversity to rural households in Eastern Cape province of South Africa. For Trees Livelihoods. 2003, 13, 39-58. [CrossRef]

28. Shackleton, S.E. The Significance of the Local Trade in Natural Resource Products for Livelihoods and Poverty Alleviation in South Africa. Ph.D. Thesis, Rhodes University, Grahamstown, South Africa, 2005.

29. Statistics South Africa (Stats SA). Census 2016: Achieving a Better Life for All: Progress between Census' 2007 and Census 2016 (No. 3); Statistics South Africa: Pretoria, South Africa, 2016.

30. Mucina, L.; Rutherford, M.C. The Vegetation of South Africa, Lesotho and Swaziland; South African National Biodiversity Institute: Pretoria, South Africa, 2006.

31. Frith, A. Thulamela Local Municipality 966 from Census 2011. Available online: https://census2011.adrianfrith.com/place/966 (accessed on 4 March 2021).

32. Municipalities of South Africa. Available online: https://municipalities.co.za/demographic/1135/thulamela-local-municipality (accessed on 4 March 2021).

33. Sachikonye, M.T.; Dalu, T.; Gunter, A. Sustainable livelihood principles and urban greening in informal settlements in practice: A case of Zandspruit informal settlement, South Africa. Dev. South. Afr. 2016, 33, 518-531. [CrossRef]

34. SPSS Inc. SPSS Release 16.0.0 for Windows; Polar Engineering and Consulting; SPSS Inc.: Chicago, IL, USA, 2007.

35. McSweeney, K. Forest product sale as natural insurance: The effects of household characteristics and the nature of shock in eastern Honduras. Soc. Nat. Resour. 2004, 17, 39-56. [CrossRef]

36. McSweeney, K. Natural insurance, forest access, and compounded misfortune: Forest resources in smallholder coping strategies before and after Hurricane Mitch, northeastern Honduras. World Dev. 2005, 33, 1453-1471. [CrossRef]

37. Makhado, R.A.; Von Maltitz, G.P.; Potgieter, M.J.; Wessels, D.C.J. Contribution of mopane woodland products to rural livelihoods in the northeast of Limpopo Province, South Africa. S. Afr. Geogr. J. 2009, 91, 46-53. [CrossRef]

38. Gwanya, T.T. South Africa Position Paper on Rural Development: A Model for the Comprehensive Rural Development Programme; Department of Rural Development and Land Reform: Pretoria, South Africa, 2010.

39. Liengme, C.A. A study of wood use for fuel and building in an area of Gazankulu. Bothalia 1983, 14, 245-257. [CrossRef]

40. Van Wyk, B.E.; Gericke, N. People's Plants: A Guide to Useful Plants of Southern Africa; Briza Publications: Pretoria, South Africa, 2000.

41. Mashabane, L.G.; Wessels, D.C.J.; Potgieter, M.J. The utilization of Colophospermum mopane by the Vatsonga in the Gazankulu region (eastern Northern Province). S. Afr. J. Bot. 2001, 67, 199-205. [CrossRef]

42. Liengme, C.A. Plants used by the Tsonga people of Gazankulu. Bothalia 1981, 13, 501-518. [CrossRef]

43. Tietema, T.; Dithlogo, M.; Tibone, C.; Mathalaza, N. Characteristics of eight firewood species of Botswana. Biomass Bioenergy 1991, 1, 41-46. [CrossRef] 